\title{
Influence of long-term mineral fertilization on metal contents and properties of soil samples taken from different locations in Hesse, Germany
}

\author{
S. Czarnecki and R.-A. Düring \\ Institute of Soil Science and Soil Conservation, Justus Liebig University, Giessen, Germany \\ Correspondence to: S. Czarnecki (sezin.czarnecki@umwelt.uni-giessen.de) \\ Received: 2 June 2014 - Published in SOIL Discuss.: 25 June 2014 \\ Revised: 23 October 2014 - Accepted: 10 November 2014 - Published: 6 January 2015
}

\begin{abstract}
Essential and non-essential metals occur in soils as a result of weathering, industrial processes, fertilization, and atmospheric deposition. Badly adapted cultivation of agricultural soils (declining $\mathrm{pH}$ value, application of unsuitable fertilizers) can enhance the mobility of metals and thereby increase their concentrations in agricultural products. As the enrichment of metals in soils occurs over long time periods, monitoring of the long-term impact of fertilization is necessary to assess metal accumulation in agricultural soils. The main objective of this study was to test the effects of different mineral fertilizer variations on soil properties $\left(\mathrm{pH}, \mathrm{C}_{\text {org }}\right.$, and cation exchange capacity (CEC)) and pseudo-total and mobile metal contents of soils after 14 years of fertilizer application and to determine residual effects of the fertilization 8 years after cessation of fertilizer treatment. Soil samples were taken from a field experiment which was carried out at four different locations $(210,260,360$, and $620 \mathrm{~m}$ above sea level) in Hesse, Germany. During the study, a significant decrease in soil $\mathrm{pH}$ and an evident increase in soil carbon content and cation exchange capacity with fertilization were determined. The CEC of the soils was closely related to their organic $\mathrm{C}$ contents. Moreover, pseudo- and mobile metal $(\mathrm{Cd}, \mathrm{Cu}, \mathrm{Mn}, \mathrm{Pb}$, $\mathrm{Zn}$ ) contents in the soils increased due to application of 14 years of mineral fertilizer treatments $(\mathrm{N}, \mathrm{P}, \mathrm{NP}$, and NPK) when compared to control plots. Eight years after termination of the fertilization in the soil samples taken from soil profiles of the fertilized plots (NPK) for monitoring the residual effects of the fertilizer application, a decrease of 82.6, 54.2, 48.5, 74.4, and 56.9\% in pseudo-total $\mathrm{Cd}, \mathrm{Cu}, \mathrm{Mn}, \mathrm{Pb}$, and $\mathrm{Zn}$ contents, respectively, was determined.
\end{abstract}

\section{Introduction}

The world population continues to increase at an alarming rate. As a result, new farmland in previously non-arable locations will be called for to help support this growing population, and more fertilizers will have to be utilized to increase food production (Hagen and Howard, 2011). There are concerns about whether continuous use of such fertilizers over a long period of time will cause an accumulation of metals to high levels, thereby increasing risk to environmental and human health (Huang et al., 2004). Fertilizers and soil amendments can contain significant amounts of potentially hazardous trace elements of geologic or man-made origin. The risk of soil and environmental pollution through the ap- plication of these materials to agricultural lands has therefore raised some concern (Raven et al., 1997). Inorganic fertilizers contain elevated quantities of metals like $\mathrm{Cd}, \mathrm{Pb}, \mathrm{As}$, and other trace elements of environmental relevance (Ajayi et al., 2012; Nicholson et al., 2003).

Metals can be toxic to humans and plants; therefore a long-term application of inorganic fertilizers, organic waste, and pesticides to soils requires a detailed risk assessment of heavy metal accumulation in agricultural lands (Papafilippaki et al., 2007). Metals required by plants include Mn, Fe, $\mathrm{Cu}, \mathrm{Zn}, \mathrm{Mo}$, and, possibly, Ni. The phytotoxicity of such relatively common metals as $\mathrm{Cd}, \mathrm{Cu}, \mathrm{Hg}$, and $\mathrm{Ni}$ is substantially greater than that of $\mathrm{Pb}$ and $\mathrm{Zn}$ (Raskin et al., 1994). 
Table 1. Basic physicochemical properties of soil samples (control plots) (mean values of four locations).

\begin{tabular}{|c|c|c|c|c|c|}
\hline \multicolumn{2}{|l|}{ Properties } & & April & August & November \\
\hline \multirow{3}{*}{\multicolumn{2}{|c|}{$\mathrm{pH}\left[\mathrm{CaCl}_{2}\right]$}} & $\min$ & 5.10 & 5.03 & 5.10 \\
\hline & & $\max$ & 5.57 & 5.82 & 5.45 \\
\hline & & mean $\pm \mathrm{SD}$ & $5.32 \pm 0.18$ & $5.28 \pm 0.32$ & $5.27 \pm 0.15$ \\
\hline \multirow{3}{*}{\multicolumn{2}{|c|}{ Clay [\%] }} & $\min$ & 24.1 & 30.0 & 27.8 \\
\hline & & $\max$ & 48.4 & 43.0 & 43.1 \\
\hline & & mean $\pm \mathrm{SD}$ & $32.9 \pm 7.9$ & $34.9 \pm 4.4$ & $34.8 \pm 4.5$ \\
\hline \multirow{3}{*}{\multicolumn{2}{|c|}{$\mathrm{C}_{\text {org }}[\%]$}} & $\min$ & 0.39 & 0.39 & 0.40 \\
\hline & & $\max$ & 0.52 & 0.51 & 0.49 \\
\hline & & mean $\pm \mathrm{SD}$ & $0.43 \pm 0.05$ & $0.42 \pm 0.03$ & $0.42 \pm 0.03$ \\
\hline \multirow{3}{*}{\multicolumn{2}{|c|}{$\mathrm{CEC}_{\text {eff }}\left[\mathrm{cmolc} \mathrm{kg}^{-1}\right]$}} & $\min$ & 9.21 & 9.23 & 9.22 \\
\hline & & $\max$ & 14.2 & 17.3 & 17.7 \\
\hline & & mean $\pm \mathrm{SD}$ & $11.9 \pm 1.83$ & $13.6 \pm 2.43$ & $13.5 \pm 2.51$ \\
\hline \multirow{15}{*}{$\begin{array}{l}\text { Aqua regia } \\
\text { extractable metals } \\
\mathrm{mg} \mathrm{kg}^{-1}\end{array}$} & $\mathrm{Cd}$ & $\min$ & 0.059 & 0.057 & 0.056 \\
\hline & & $\max$ & 0.190 & 0.190 & 0.190 \\
\hline & & mean $\pm \mathrm{SD}$ & $0.097 \pm 0.04$ & $0.093 \pm 0.05$ & $0.095 \pm 0.04$ \\
\hline & $\mathrm{Cu}$ & $\min$ & 8.92 & 9.81 & 8.99 \\
\hline & & $\max$ & 12.0 & 18.1 & 15.9 \\
\hline & & mean $\pm \mathrm{SD}$ & $10.3 \pm 0.73$ & $11.4 \pm 2.22$ & $11.7 \pm 2.08$ \\
\hline & $\mathrm{Mn}$ & $\min$ & 538.9 & 532.2 & 533.6 \\
\hline & & $\max$ & 786.0 & 782.2 & 785.3 \\
\hline & & mean $\pm \mathrm{SD}$ & $627.3 \pm 98.6$ & $624.4 \pm 99.9$ & $631.0 \pm 97.5$ \\
\hline & $\mathrm{Pb}$ & $\min$ & 8.01 & 8.12 & 8.12 \\
\hline & & $\max$ & 19.1 & 19.4 & 19.2 \\
\hline & & mean $\pm \mathrm{SD}$ & $11.3 \pm 4.62$ & $11.4 \pm 4.61$ & $11.3 \pm 4.54$ \\
\hline & $\mathrm{Zn}$ & $\min$ & 41.1 & 42.0 & 41.0 \\
\hline & & $\max$ & 87.4 & 87.3 & 86.6 \\
\hline & & mean $\pm \mathrm{SD}$ & $63.5 \pm 17.9$ & $63.3 \pm 17.6$ & $63.1 \pm 17.9$ \\
\hline
\end{tabular}

$\mathrm{CEC}_{\text {eff }}$ : effective cation exchange capacity, $\mathrm{C}_{\text {org }}$ : soil organic carbon.

Cadmium concentrations in soils in many countries are increasing due to inadvertent additions in fertilizer, biosolids, and soil amendments, as well as additions from the atmosphere (McLaughlin et al., 1999). The management of phosphate $(\mathrm{P})$ fertilizer application, both in the short and long term, can influence the potential accumulation of $\mathrm{Cd}$ in foods. The Cd added to agricultural systems in P fertilizers accumulates over time if application rates are in excess of $\mathrm{Cd}$ removal as an effect of long-term $\mathrm{P}$ fertilizer application (Grant, 2011). Nicholson et al. (2003) predicated that $P$ fertilizers, in particular, are an important source of metals, particularly for $\mathrm{Zn}, \mathrm{Cu}$, and $\mathrm{Cd}$, entering agricultural soils. The increase in $\mathrm{Cu}$ and $\mathrm{Zn}$ in soils is associated mainly with NPK fertilizers (Kabata-Pendias, 2011). High application rates of nitrogen fertilizer to agricultural soils resulted in increased accumulation of some heavy metals such as $\mathrm{Cd}$ and $\mathrm{Pb}$ in agricultural products (Zhou, 2003).

In this study we analyzed soils from long-term fertilizer experiments in Hesse, Germany. We investigated the longterm effects of different NPK fertilizer regimes on soil properties and soil metal contents. Therefore, the aim of this paper was to answer the following question: how do (1) soil organic carbon content and cation exchange capacity, (2) soil $\mathrm{pH}$, and (3) pseudo- and mobile concentrations of metals differ between fertilized and control plots after 14 years of fertilizer application and after 8 years of fertilization termination in Hesse, Germany?

\section{Materials and methods}

\subsection{Study area and fertilizer treatments}

This study was carried out at four different locations at different altitudes in Hesse, Germany. The region has a climate with a relative strongly maritime influence. Different doses of nitrogen, phosphorus, and potassium fertilization were administered between 1986 and 2002 in a Latin rectangle design, including the control treatment that did not receive any fertilizers to verify metal input due to fertilizer treatments. Some basic physicochemical characteristics of the non-fertilized (control) plots in the studied areas are given in Table 1.

The size of the field trial was $45 \mathrm{~m} \times 54 \mathrm{~m}$ and divided into 81 plots each of $30 \mathrm{~m}^{2}$ size. The topsoil $(0-30 \mathrm{~cm})$ was sampled in April, August, and November in three replications in 
Table 2. Fertilization variations of the study sites.

\begin{tabular}{lrrr}
\hline & \multicolumn{3}{c}{$\mathrm{kg} \mathrm{ha}^{-1}$} \\
\cline { 2 - 4 } Fertilizer variations & $\mathrm{N}$ & $\mathrm{P}_{2} \mathrm{O}_{5}$ & $\mathrm{~K}_{2} \mathrm{O}$ \\
\hline Control & 0 & 0 & 0 \\
N & 320 & 0 & 0 \\
P & 0 & 120 & 0 \\
NP & 320 & 120 & 0 \\
NPK & 320 & 120 & 160 \\
\hline
\end{tabular}

the year 2000 (14 years after fertilization application) and in July 2011 from soil profiles (8 years after fertilization termination). According to the WRB (World Reference Base for Soil Resources) classification (2014), we determined the soil types as Eutric Cambisol (210 m a.s.l), Skeletic Cambisol (260 and $360 \mathrm{~m}$ a.s.l), and Gleyic Fluvisol (620 m a.s.1). Lolio-Cynosuretum was the cultivation crop during the study.

Calcium ammonium nitrate (CAN) $\left(74 \% \mathrm{NH}_{4} \mathrm{NO}_{3}\right.$, $\left.26 \% \mathrm{CaCO}_{3}\right)$ as $\mathrm{N}$ fertilizer, hyperphosphate $\left(26 \% \mathrm{P}_{2} \mathrm{O}_{5}\right)$ and superphosphate $\left(16-22 \% \mathrm{P}_{2} \mathrm{O}_{5}\right)$ as $\mathrm{P}$ fertilizer, and Magnesia-Kainit $\left(11 \% \mathrm{~K}_{2} \mathrm{O}, 5 \% \mathrm{MgO}, 20 \% \mathrm{Na}, 4 \% \mathrm{~S}\right)$, and $\mathrm{K}_{2} \mathrm{SO}_{4}$ as $\mathrm{K}$ fertilization were used in various levels which refer to different application rates (Table 2). $\mathrm{N}$ fertilization was used in the same proportions the in middle of April, May, June, and July; P and $\mathrm{K}$ fertilizers were applied in the middle of April as hyperphosphate and Magnesia-Kainit and in the middle of June as superphosphate and $\mathrm{K}_{2} \mathrm{SO}_{4}$.

\subsection{Analytical procedures}

Soil samples were air-dried, crushed, homogenized, and sieved through a $2 \mathrm{~mm}$ screen for the analysis of physical and chemical characteristics and stored in clean, $\mathrm{HNO}_{3}$-treated plastic bottles.

The characteristics of soil such as soil pH (DIN ISO 10390, 2005), soil carbonate content (DIN ISO 10693, 1997), and particle size distribution (DIN ISO 11277, 2002) were determined for the samples collected. Moreover, total contents of carbon $\left(\mathrm{C}_{t}\right)$ were examined on finely ground samples using a CNS analyzer with a thermal conductivity detector (VarioEL III Elementar, Germany). Inorganic carbon $\left(\mathrm{C}_{\mathrm{i}}\right)$ was calculated from the carbonate content by multiplying by a factor of 0.1199 . The amounts of organic $\mathrm{C}\left(\mathrm{C}_{\mathrm{org}}\right)$ resulted from the difference between $\mathrm{C}_{t}$ and $\mathrm{C}_{\mathrm{i}}$. Effective cation exchange capacity $\left(\mathrm{CEC}_{\text {eff }}\right)$ was examined with $\mathrm{NH}_{4} \mathrm{Cl}$ extraction according to Trüby and Aldinger (1989) and exchangeable cations were determined with AAS (AA240FS, Varian, USA).

Pseudo-total metal contents of soil samples were determined with modified USEPA method 3051A (USEPA, 1998) with microwave-assisted aqua regia extraction (MAE-AR). The modified program for MAE-AR $(0.3 \mathrm{~g}$ of soil, $6 \mathrm{~mL}$ of $\mathrm{HCl}$, and $2 \mathrm{~mL}$ of $\mathrm{HNO}_{3}$ ) is described in Öztan and
Table 3. Effect of fertilizers on soil pH (mean values of four locations).

\begin{tabular}{llccc}
\hline Fertilizer & Value & $\mathrm{pH}($ April) & $\mathrm{pH}$ (August) & $\mathrm{pH}$ (November) \\
\hline Control & $\min$ & 5.10 & 5.03 & 5.10 \\
& $\max$ & 5.57 & 5.82 & 5.45 \\
& $\operatorname{mean} \pm \mathrm{SD}$ & $5.32 \pm 0.18^{\mathrm{a}}$ & $5.28 \pm 0.32^{\mathrm{a}}$ & $5.27 \pm 0.15^{\mathrm{a}}$ \\
\hline $\mathrm{N}$ & $\min$ & 4.00 & 4.99 & 4.07 \\
& $\max$ & 5.07 & 5.16 & 5.18 \\
& $\operatorname{mean} \pm \mathrm{SD}$ & $4.76 \pm 0.43^{\mathrm{b}}$ & $5.07 \pm 0.05^{\mathrm{ab}}$ & $4.78 \pm 0.44^{\mathrm{b}}$ \\
\hline $\mathrm{P}$ & $\min$ & 4.53 & 5.00 & 4.90 \\
& $\max$ & 5.16 & 5.26 & 5.07 \\
& $\operatorname{mean} \pm \mathrm{SD}$ & $4.96 \pm 0.25^{\mathrm{b}}$ & $5.06 \pm 0.07^{\mathrm{ab}}$ & $5.00 \pm 0.05^{\mathrm{abc}}$ \\
\hline $\mathrm{NP}$ & $\min$ & 4.52 & 4.66 & 4.49 \\
& $\max$ & 5.07 & 5.05 & 5.09 \\
& $\operatorname{mean} \pm \mathrm{SD}$ & $4.80 \pm 0.24^{\mathrm{b}}$ & $4.88 \pm 0.13^{\mathrm{b}}$ & $4.90 \pm 0.23^{\mathrm{b}}$ \\
\hline $\mathrm{NPK}$ & $\min$ & 4.20 & 4.19 & 4.35 \\
& $\max$ & 5.08 & 5.02 & 5.09 \\
& $\operatorname{mean} \pm \mathrm{SD}$ & $4.78 \pm 0.33^{\mathrm{b}}$ & $4.64 \pm 0.35^{\mathrm{c}}$ & $4.71 \pm 0.32^{\mathrm{b}}$ \\
\hline Mean values followed by different superscript letters between fertilizer variations differ at $5 \%$ \\
probability.
\end{tabular}

Düring (2012). Mobile fraction of metals was measured after the extraction of soils with ammonium nitrate $\left(\mathrm{NH}_{4} \mathrm{NO}_{3}\right)$ ( $20 \mathrm{~g}$ of soil, $50 \mathrm{~mL}$ of $1 \mathrm{M} \mathrm{NH}_{4} \mathrm{NO}_{3}$, shaken for $120 \mathrm{~min}$ ) (DIN 19730, 2009). Metal concentrations in soil extracts were determined by means of an inductively coupled plasmaoptical emission spectrometer (ICP-OES; Agilent 720ES), which provides rapid multi-elemental analysis.

The reagents used were all of analytical-reagent grade certified for the impurities. Distilled and deionized water, purified with a Milli-Q plus system (Merck Millipore, Darmstadt, Germany), was used for the experiments. For quality assurance, two certified reference materials (CRMs), "7001" (light sandy soil) and "7004" (loam), from Analytika Co. Ltd., Prague, Czech Republic, were analyzed repeatedly during analysis of the sample set. To designate the amount of possible cross contamination, blank values were determined within each sample series.

\subsection{Statistics}

For data analysis, SPSS 19.0 for Windows was used. Before testing for differences in analyte concentrations, each element across samples was tested for normality by examination of histograms and residual plots. All data were subjected to analysis of variance (ANOVA) to determine the main effect of each fertilizer variation on soil metal content and soil properties at the $p<0.05$ probability level.

\section{Results and discussion}

The results show that long-term $\mathrm{N}, \mathrm{P}$, and $\mathrm{K}$ fertilizer treatments have significant effects on soil properties. During the study, a significant decrease in soil $\mathrm{pH}$ was detected due to fertilization (Table 3). The decrease in $\mathrm{pH}$ of the surface layer in the fertilizer might be attributed to the nitrifi- 

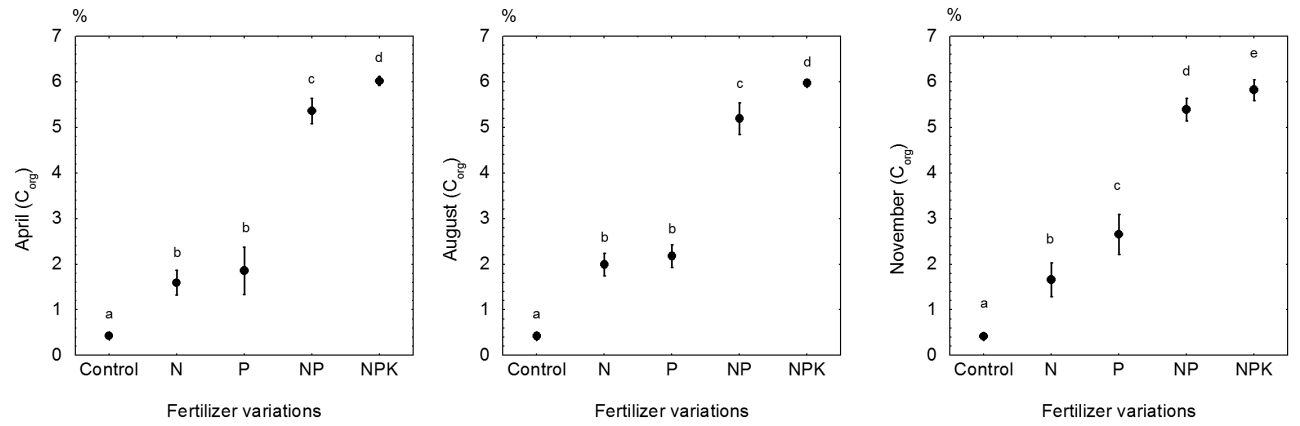

Figure 1. Effect of fertilizers on soil organic carbon content (mean values of four study areas. Error bars indicate standard deviation).
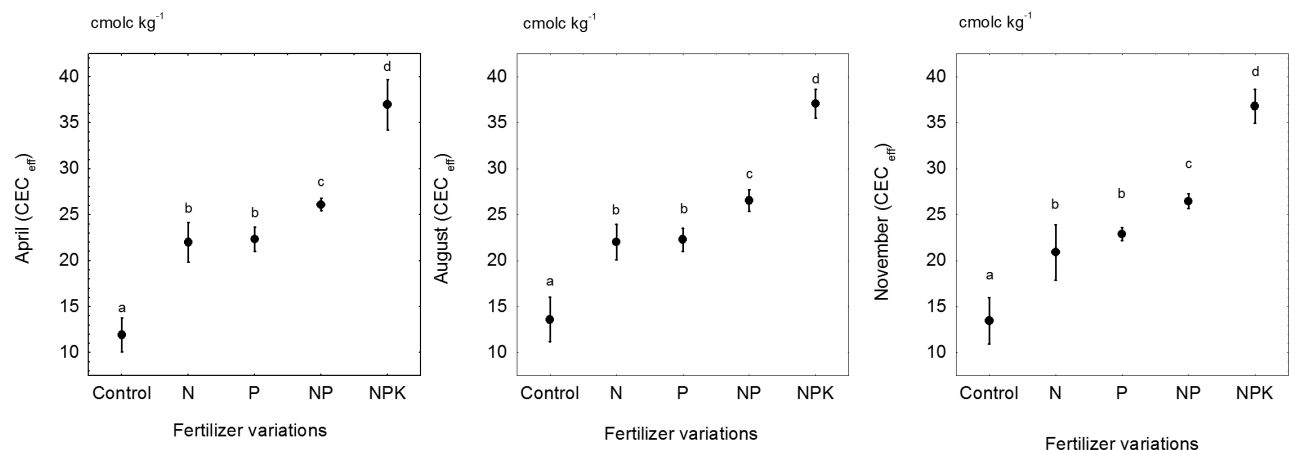

Figure 2. Effect of fertilizers on soil effective cation exchange capacity (mean values of four study areas. Error bars indicate standard deviation).

cation and acidification processes stimulated by continuous application of fertilizers as well as by $\mathrm{H}^{+}$released by roots (Liang et al., 2012). Where $\mathrm{N}$ fertilizer was applied, the $\mathrm{pH}$ slightly decreased with respect to the initial value. Significant differences were determined between the control plots and N, P, NP, and NPK applications in soil pH level in April. However a decrease in soil $\mathrm{pH}$ was found when compared to control plots in soil-August and November $\mathrm{pH}$ degrees; no significant differences were seen for $\mathrm{N}$ and $\mathrm{P}$ treatments in soil-August and for $\mathrm{P}$ application in soil-November $\mathrm{pH}$ level (Table 3). Continued use of ammonia-based fertilizers can induce soil acidity (Schwab et al., 1990). Results from the study were in agreement with the findings of Tsadilas et al. (2005), who reported that the application of ammonium fertilizer significantly decreased soil $\mathrm{pH}$ more than the nitrate treatments. Results from a pot fertilizer experiment by Liu et al. (2007) showed that application of $\mathrm{NH}_{4} \mathrm{Cl}$ lowered soil $\mathrm{pH}$ from 4.51 to 4.07 . The major mechanism of soil acidification by $\mathrm{N}$ fertilization is related to hydrogen ion $\left(\mathrm{H}^{+}\right)$ release through nitrification of $\mathrm{NH}_{4}^{+}$and subsequent leaching of $\mathrm{NO}_{3}^{-}$. The most important acid forming reaction by fertilizers is microbial oxidation of ammoniacal fertilizers (Barak et al., 1997).

Significant differences in soil organic carbon $\left(\mathrm{C}_{\text {org }}\right)$ content and effective cation exchange capacity $\left(\mathrm{CEC}_{\text {eff }}\right)$ which were caused by fertilization treatments can be seen in Figs. 1 and 2. A significant increase in $\mathrm{C}_{\text {org }}$ content was determined in April, August, and November soil samples. All fertilizer treatments show significant differences when compared to the control plots. In April and August soil samples, no significant differences were determined on $\mathrm{C}_{\mathrm{org}}$ content between $\mathrm{N}$ and $\mathrm{P}$ treatments. Differences between $\mathrm{N}$ and $\mathrm{P}$ variations are evident in November $\mathrm{C}_{\text {org }}$ content. $\mathrm{C}_{\text {org }}$ level with $\mathrm{P}$ fertilizer was almost 2 times higher than $\mathrm{C}_{\text {org }}$ content in $\mathrm{N}$ treatment (Fig. 1). Addition of fertilizers to soil influences the chemical composition of soil solution. Increased plant biomass produced by fertilizers results in increased returns of organic material to the soil in the form of decaying roots, litter, and crop residues (Haynes and Naidu, 1998). Our results are similar with the findings of Raun et al. (1998) and with the study of Halvorson et al. (1999), who demonstrated a rise in $\mathrm{C}_{\text {org }}$ with the applied increasing $\mathrm{N}$ ratios. Messiga et al. (2013) noted a tendency of greater total carbon concentration with increasing $\mathrm{N}$ application. Liu et al. (2005) reported that $\mathrm{C}_{\text {org }}$ in the surface soil $(0-15 \mathrm{~cm})$ layer was $7.7 \%$ higher in mineral fertilizer treatment than without fertilizer application. Similar results obtained in a long-term experiment showed that low nitrogen rates poorly increased $\mathrm{C}_{\text {org }}$ content compared to the control ( 0.14 vs. $0.03 \mathrm{Mg} \mathrm{ha}^{-1}$ year $^{-1}$ ), while the medium and high rates increased it by 0.45 and $0.49 \mathrm{Mg} \mathrm{ha}^{-1}$ year $^{-1}$, respectively (Mazzoncini et al., 2011). After 14 years of fertilizer application, there was an increas- 

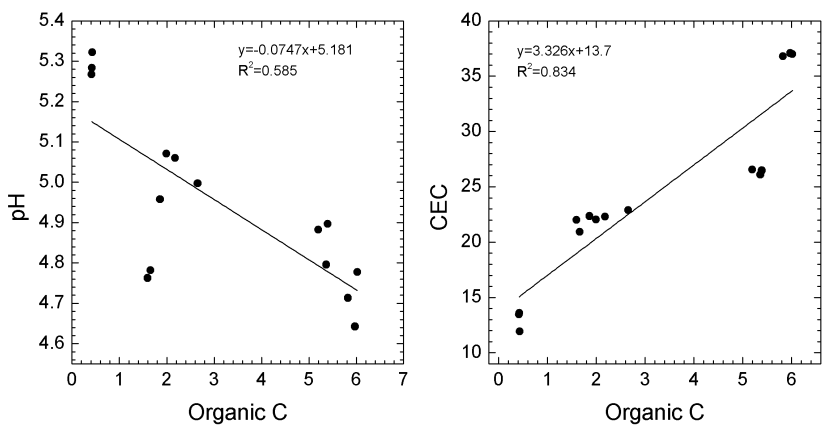

Figure 3. Relationship between organic $\mathrm{C}$ and $\mathrm{pH}$ and soil $\mathrm{CEC}_{\mathrm{eff}}$ using mean values of all treatments (mean values of four study areas).

ing trend to $\mathrm{C}_{\text {org }}$ in April in NPK treatment (6.02\%), contrasting with the control soil content of $0.43 \%$. This is in accordance with the results of Xie et al. (2011), who, in a pot experimental study, found the highest $\mathrm{C}_{\text {org }}$ content was in the NPK $\left(80 \mathrm{~N} \mathrm{mg} \mathrm{kg}^{-1}, 35 \mathrm{P} \mathrm{mg} \mathrm{kg}^{-1}\right.$, and $60 \mathrm{~K} \mathrm{mg} \mathrm{kg}^{-1}$ ) treatment, which was significantly higher than that in the NK $\left(80 \mathrm{~N} \mathrm{mg} \mathrm{kg}^{-1}\right.$ and $\left.60 \mathrm{~K} \mathrm{mg} \mathrm{kg}^{-1}\right)$ treatment. Gong et al. (2009) determined an increase in $\mathrm{C}$ with long-term applications of manures and mineral fertilizers - both alone and in combination - and concluded that application of mineral fertilizer may have stimulated microbial activity and enhanced decomposition. More soil organic matter was decomposed and more available nutrients could then be provided for better crop growth, resulting in increased crop residues (root debris and secretion) being returned to the soil.

The CEC is a very important soil property for nutrient retention and supply and acts as a bridge between soil and plant (Caravaca et al., 1999). N, P, NP, and NPK treatments significantly increased CEC in April, August, and November soil samples when compared to non-fertilized plots (Fig. 2). Cakmak et al. (2010) reported that 40 years of application of $\mathrm{P}$ fertilizers significantly decreased $\mathrm{pH}$ and increased CEC of the soil. Thus, phosphate fertilizer applications not only increase $\mathrm{Cd}$ concentration of soils but also may change their chemical speciation and thus bioavailability. As the unfertilized soil in our study did not receive any kind of fertilizer during 14 years of investigation, the differences observed here may therefore be judged as conservative estimates of the effect of soil organic matter on CEC. This is in accordance with the results of Schjonning et al. (1994), who found $11 \%$ higher CEC than in the control plots. Nitrogen application as CAN fertilizer only or in combination with NPK complex fertilizer raises the soil CEC value. This can be explained by soil colloid retention of applied $\mathrm{Ca}^{2+}, \mathrm{NH}_{4}^{+}$, and $\mathrm{K}^{+}$ions (Radulov et al., 2011) and by the organic carbon content of soil, which is the most important factor affecting soil CEC (Rashidi and Seilsepour, 2008). Positive linear relationships were determined between $\mathrm{C}_{\text {org }}$ and CEC (Fig. 3). The CEC of the soils were closely related to their organic $\mathrm{C}$ contents (Car-

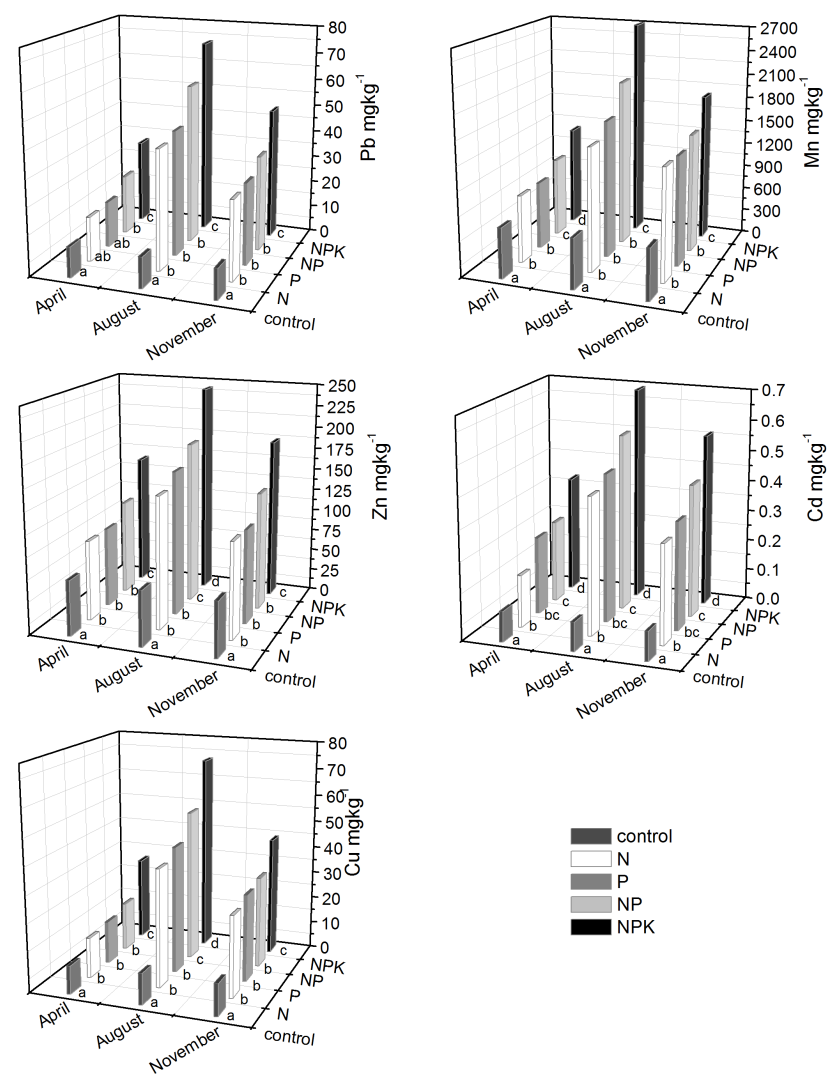

Figure 4. Effect of fertilizer treatments on pseudo-total (aqua regia) metal contents in soil samples (mean values followed by different superscript letters for each month between the fertilizer variations differ at $5 \%$ probability).

avaca et al., 1999). In contrast to observations in other recent studies (Bationo et al., 2007), a significant negative linearity between soil $\mathrm{pH}$ and organic carbon content was found (Fig. 3). There are two possible explanations for these adverse observations: either organic matter accumulation does not necessarily result in $\mathrm{pH}$ decreases or other mechanisms causing $\mathrm{pH}$ change are more dominant (Ritchie and Dolling, 1985). In particular, accumulation of undecomposed soil organic matter rich in organates and inputs of symbiotically fixed $\mathrm{N}$ and ammonium-based fertilizers with consequent nitrate leaching are involved in the accelerated acidification of agricultural soils (Bolan and Hedley, 2003). Acidification from soil organic matter accumulation or the direct effects of fertilizers on the soil chemistry can, however, be of significant importance (de Klein et al., 1997). Schwab et al. (1990) determined a decrease in soil $\mathrm{pH}$ and an increase in soil organic matter content due to applied high $\mathrm{N}$ rate.

The main effect of each fertilizer variation on soil pseudototal and mobile $\left(\mathrm{NH}_{4} \mathrm{NO}_{3}\right.$-extractable) metal $(\mathrm{Cd}, \mathrm{Cu}, \mathrm{Mn}$, $\mathrm{Pb}$, and $\mathrm{Zn}$ ) contents can be seen in Figs. 4 and 5. Though total concentrations of metals in soil are used to characterize its baseline elemental composition (parent geological mate- 

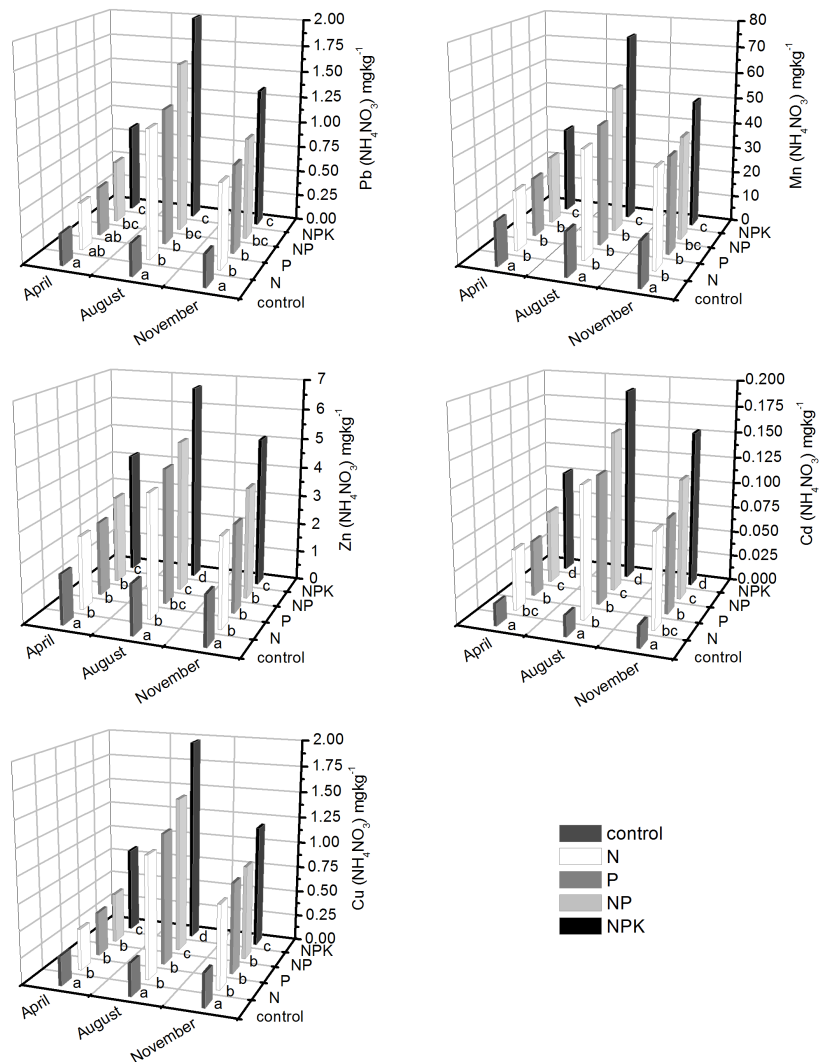

Figure 5. Effect of fertilizer treatments on mobile $\left(\mathrm{NH}_{4} \mathrm{NO}_{3}\right)$ metal contents in soil samples (mean values followed by different superscript letters for each month between the fertilizer variations differ at $5 \%$ probability).

rial), pseudo-total metal concentration analysis, which is performed by means of an estimation with aqua regia, allows for assessment of soil pollution and ascertainment of heavy metal and other pollutant contents in the soil (Ure, 1990). Pseudo-total metal contents in soils increased due to application of long-term chemical fertilizer treatments when compared to control plots (Fig. 4). Applications of N, P, NP, and NPK fertilizers increased soil April, August, and November Cd levels compared to non-fertilized soil, but no significant differences were found between $\mathrm{P}$ and NP fertilizer variations for pseudo-total Cd concentrations (Fig. 4). Significant differences between $\mathrm{P}$ and NP applications were obtained for mobile Cd content (Fig. 5). Trace metal enrichment in soils through mineral fertilizer applications is well documented for Cd. Loganathan et al. (1997) reported that 10 years of $\mathrm{P}$ fertilizer application in pasture systems in New Zealand caused a marked increase in surface soil pseudo-total Cd concentration. Identical findings reported Gray et al. (1999), who specified a significant increase in total $\mathrm{Cd}$ concentration in soils under pasture with application of superphosphate fertilizer over a period of 44 years in New Zealand.
No significant differences were determined between $\mathrm{N}, \mathrm{P}$, and NP fertilizer variations for pseudo-total soil $\mathrm{Cu}$ concentrations in April and November, but the August $\mathrm{Cu}$ level increased significantly with NP application (Fig. 4). The same effects can be seen for mobile $\left(\mathrm{NH}_{4} \mathrm{NO}_{3}\right.$-extractable) $\mathrm{Cu}$ content (Fig. 5). Thomas et al. (2012) reported that total Zn, $\mathrm{Cu}$, and $\mathrm{Cd}$ concentrations show an increase in the soil concentration with an increase in levels of phosphate fertilizer.

Although NP fertilizer applications show significant differences to $\mathrm{N}$ and $\mathrm{P}$ treatments for soil-April Mn concentration, no significant differences were obtained by addition of $\mathrm{NP}$ when compared to $\mathrm{N}$ and $\mathrm{P}$ fertilization variations for $\mathrm{Au}-$ gust and November Mn levels (Fig. 4). Soil mobile Mn concentration increased due to fertilizer application. Significant differences were observed between NPK and NP treatments for April and August, but no significant differences were determined for November Mn concentrations (Fig. 5).

April $\mathrm{Pb}$ concentrations increased in $\mathrm{N}$ and $\mathrm{P}$ fertilizer variations; however no significant effects were found in $\mathrm{Pb}$ contents when compared to control plots (Fig. 4). No significant differences were noted on soil-August and November $\mathrm{Pb}$ mobile concentrations among NP and NPK treatments (Fig. 5), whereas distinct significant differences were obtained for pseudo-total contents (Fig. 4). A recent research showed that the amount of hot acid-extractable $\mathrm{Pb}$ in the 0 $30 \mathrm{~cm}$ soil interval increased significantly $(p<0.05)$ in accordance with the amount of added $\mathrm{P}$ fertilizers (Cakmak et al., 2010). Our results agree with the findings of Atafar et al. (2010), who reported that total $\mathrm{Cd}, \mathrm{Pb}$, and As concentrations increased in the cultivated soils due to fertilizer application.

Addition of fertilizer at all rates increased the soil $\mathrm{Zn}$ level when compared to control plots. Soil pseudo-total $\mathrm{Zn}$ concentration increased from $63.1 \mathrm{mg} \mathrm{kg}^{-1}$ in control treatment to $151.5,242.5$, and $185.4 \mathrm{mg} \mathrm{kg}^{-1}$ in April, August, and November $\mathrm{Zn}$ concentrations in NPK application, respectively. The highest $\mathrm{Zn}$ concentration in soils in August recorded in NPK treatment was probably related to lower soil $\mathrm{pH}$ (4.64). Based on the results, $\mathrm{Zn}$ content in soils increased significantly with $\mathrm{N}$ and $\mathrm{P}$ applications, but no significant increase was determined between $\mathrm{N}$ and $\mathrm{P}$ treatments (Fig. 4). Significant differences between NP and $\mathrm{P}$ treatments were found in pseudo-total soil-August Zn concentration (Fig. 4); however, no significant differences were noted for mobile $\mathrm{Zn}$ level for the same fertilizer variations (Fig. 5).

Soils have a distinct influence on human health (Brevik and Sauer, 2014); hence soil contaminants constitute a known global problem, and more knowledge is required regarding their behavior, as well as their pathways to humans (Abrahams, 2002). Although many grassland fertilizer experiments have been performed worldwide, information about residual effects of fertilizer applications on grassland ecosystem functioning is still rare (Hejcman and Schnellberg, 2009). Fertilization is one of the major paths for metal input to agricultural soils; therefore monitoring of the long- 
Table 4. Soil pseudo- and mobile metal contents $(\mathrm{Cd}, \mathrm{Cu}, \mathrm{Mn}, \mathrm{Pb}$, $\mathrm{Zn}$ ) and soil $\mathrm{pH}, \mathrm{C}_{\text {org }}$, and CEC of the soil profiles in July 2011 in the four study areas.

\begin{tabular}{|c|c|c|c|c|}
\hline \multicolumn{2}{|c|}{ Properties } & Min & Max & Mean \\
\hline \multicolumn{2}{|c|}{$\mathrm{pH}\left[\mathrm{CaCl}_{2}\right]$} & 4.03 & 5.98 & 5.14 \\
\hline \multicolumn{2}{|c|}{$\mathrm{C}_{\text {org }}[\%]$} & 0.31 & 4.58 & 2.09 \\
\hline \multicolumn{2}{|c|}{$\mathrm{CEC}_{\mathrm{eff}}\left[\mathrm{cmolc} \mathrm{kg}^{-1}\right]$} & 20.4 & 23.8 & 21.3 \\
\hline \multirow{5}{*}{$\begin{array}{l}\text { Aqua regia } \\
\text { Extractable } \\
\text { Metals } \\
\mathrm{mg} \mathrm{kg}^{-1}\end{array}$} & $\mathrm{Cd}$ & 0.08 & 0.19 & 0.12 \\
\hline & $\mathrm{Cu}$ & 20.7 & 54.9 & 33.1 \\
\hline & $\mathrm{Mn}$ & 993.0 & 1867.5 & 1390.2 \\
\hline & $\mathrm{Pb}$ & 6.66 & 38.9 & 18.6 \\
\hline & $\mathrm{Zn}$ & 87.1 & 146.3 & 104.5 \\
\hline \multirow{5}{*}{$\begin{array}{l}\mathrm{NH}_{4} \mathrm{NO}_{3} \\
\text { Extractable } \\
\text { Metals } \\
\mathrm{mg} \mathrm{kg}^{-1}\end{array}$} & $\mathrm{Cd}$ & 0.00 & 0.08 & 0.02 \\
\hline & $\mathrm{Cu}$ & 0.03 & 0.22 & 0.11 \\
\hline & $\mathrm{Mn}$ & 1.20 & 48.2 & 21.7 \\
\hline & $\mathrm{Pb}$ & 0.00 & 0.19 & 0.02 \\
\hline & $\mathrm{Zn}$ & 0.01 & 1.45 & 0.50 \\
\hline
\end{tabular}

term impact of fertilization residual effects is necessary. On this account, in July 2011, mixed soil samples from soil profiles of the fertilized plots (NPK) in the study areas were taken and analyzed for pseudo-total and mobile metal concentration and for soil properties such as $\mathrm{pH}, \mathrm{C}_{\text {org }}$, and CEC. Soil pseudo- and mobile metal contents ( $\mathrm{Cd}, \mathrm{Cu}, \mathrm{Mn}, \mathrm{Pb}, \mathrm{Zn})$ and soil $\mathrm{pH}, \mathrm{C}_{\text {org }}$, and $\mathrm{CEC}$ of the soil profiles are summarized in Table 4 and detailed distributions of the metals in soil profiles are given in Fig. A1 in the Appendix.

After 8 years of finalization of the experimental fertilization design, an element-specific decrease in pseudo-total $\mathrm{Cd}, \mathrm{Cu}, \mathrm{Mn}, \mathrm{Pb}$, and $\mathrm{Zn}$ concentration in soil samples was determined. Compared to the pseudo-total contents of the soil samples taken in August 2000, Cd concentrations evidently decreased in the whole soil profile. In $2011 \mathrm{Cd}$ contents in the upper soil layers decreased down to the value in the control plots determined in August 2000. Cd content in the studied soils in August 2000 was in the range of 0.06$0.19 \mathrm{mg} \mathrm{kg}^{-1}$ with a mean value of $0.10 \pm 0.05 \mathrm{mg} \mathrm{kg}^{-1}$ in plots without fertilization, and in NPK treated plots $\mathrm{Cd}$ content was between 0.64 and $0.78 \mathrm{mg} \mathrm{kg}^{-1}$ (Fig. 4). In July $2011 \mathrm{Cd}$ concentrations in treated plots were between 0.08 and $0.19 \mathrm{mg} \mathrm{kg}^{-1}$ with a mean value of $0.12 \mathrm{mg} \mathrm{kg}^{-1}$ (Table 4). Decrease in soil Cd concentration could be due to its mobility and its uptake by plants. Soil $\mathrm{Cd}$ is mostly adsorbed at exchange sites, and its plant availability is closely related to $\mathrm{pH}$ and soil organic matter content (Puschenreiter and Horak, 2000).

Furthermore, though a decrease in $\mathrm{Cu}, \mathrm{Mn}, \mathrm{Pb}$, and $\mathrm{Zn}$ contents was determined in the first $30 \mathrm{~cm}$ of the soil profiles in July 2011, an evident decrease such as in Cd concentration was not observed. Detected pseudo-total $\mathrm{Cu}, \mathrm{Mn}, \mathrm{Pb}$, and $\mathrm{Zn}$ concentrations in August 2000 in NPK-amended plots were $72.3,2704.4,72.8$, and $242.5 \mathrm{mg} \mathrm{kg}^{-1}$, and in non- fertilized plots (control treatment) were 11.4, 624.4, 11.4, and $63.3 \mathrm{mg} \mathrm{kg}^{-1}$, respectively (Fig. 4). High contents of $\mathrm{Cu}$, $\mathrm{Mn}, \mathrm{Pb}$, and $\mathrm{Zn}$ from fertilizers residual effects still persisted in the topsoil layer of the field trial in July 2011. In the soils that received the maximum dose of fertilization (NPK) for 14 years and are followed by no additional input for 8 years, $\mathrm{Cu}, \mathrm{Mn}, \mathrm{Pb}$, and $\mathrm{Zn}$ contents were still around 2 times higher than those in the control plots in August 2000 (Fig. A1).

These metals do not show this mobility in soils like $\mathrm{Cd}$ does, so $\mathrm{Pb}$ can be regarded more or less as permanent in soils (Alloway, 1990). Moreover, the absorption of $\mathrm{Pb}$ by roots is passive and thus the rate of its uptake from soils is rather low (Kabata-Pendias and Mukherjee, 2007).

The increase in metal contents in soil due to fertilization should be considered not only a matter of soil contamination but also a potential risk for human health. The precaution values for soils were chosen as criteria in terms of correlations between metal contamination and human health. Precaution values according to BBodSchV (1999) for $\mathrm{Cd}, \mathrm{Pb}, \mathrm{Cu}$, and $\mathrm{Zn}$ are $1,70,40$, and $150 \mathrm{mg} \mathrm{kg}^{-1}$, respectively. However, in the samples taken from $2000, \mathrm{Cd}, \mathrm{Cu}$, and $\mathrm{Pb}$ contents mostly were below the precaution levels, and $\mathrm{Zn}$ concentration $\left(151.5 \mathrm{mg} \mathrm{kg}^{-1}\right.$ in NPK treated plots) just met or exceeded the precaution values. The metal concentrations determined in the samples taken from 2011 all fell below the precaution values. However, $\mathrm{Pb}$ showed some residual effect as it could still be determined in higher concentrations in the upper soil layer.

In the soil samples taken in August 2000, significant increase in $\mathrm{C}_{\text {org }}$ and CEC content was determined in April, August and November due to N, P, NP, and NPK treatments when compared to non-fertilized plots (Figs. 1 and 2). Rasool and colleagues reported that $\mathrm{N}_{100} \mathrm{P}_{50} \mathrm{~K}_{50}$ increased soil organic matter content by $21 \%$ (Rasool et al., 2008). After finalization of the fertilization design, an appreciable decrease in July 2011 soil $\mathrm{C}_{\text {org }}$ and CEC was detected (Table 4). Grassland has suffered throughout centuries from nutrient depletion through removal of organic material as dung and forage and subsequent transfer to agricultural land or highly productive lowland grassland (Hejcman and Schnellberg, 2009).

\section{Conclusions}

Based on the results from the present study, the main conclusion is that 14 years of mineral fertilization has a significant effect on soil metal contents and soil properties such as $\mathrm{pH}$, $\mathrm{C}_{\text {org }}$, and $\mathrm{CEC}_{\text {eff }}$ and therefore has a great impact on metal availability. Continued long-term fertilizer use increased soil metal content, soil organic C, CEC, and decreased soil $\mathrm{pH}$ level. Another important aspect of this study was the establishment of soil metal concentrations 8 years after cessation of the fertilizer application. Soluble metals were taken up by plants, thus leaving lower amounts in the soil, probably 
due to decreased $\mathrm{pH}$ values in the long-term fertilized soils. Cd concentrations in 2011 evidently decreased down to the value in the control plots determined in August 2000. Despite decrement in metal contents, $\mathrm{Cu}, \mathrm{Mn}, \mathrm{Pb}$, and $\mathrm{Zn}$ still remained in the topsoil profile around 2 times higher than the control soils taken 14 years after fertilization application. Moreover, in terms of human health, metal concentrations determined in the samples taken in 2011 all fell below the precaution values according to BBodSchV (1999).
This research has brought forth some questions that are in need of further investigation. Applications of fertilizers not only provide plant nutrients but also change the availability of metals and their uptake into the plants. As plants represent the first compartment of the terrestrial food chain, future research should therefore concentrate on the investigation of the impacts of various soil factors on metal transfer into the plants. 
Appendix A
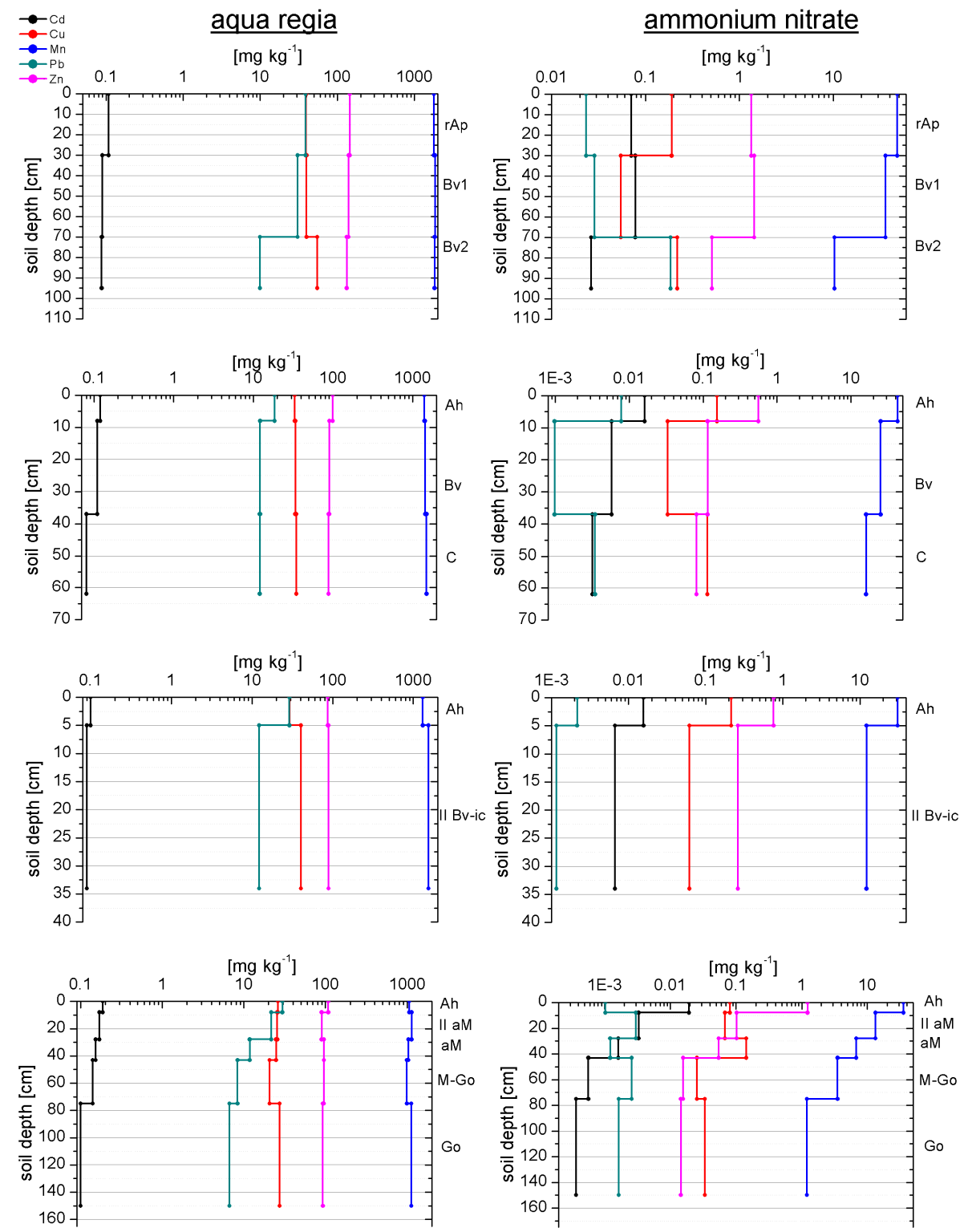

Figure A1. Soil pseudo- and mobile metal contents (Cd, Cu, Mn, Pb, Zn) of the soil profiles in 2011. 
Edited by: T. Miano

\section{References}

Abrahams, P. W.: Soils: their implications to human health, Sci. Total Environ., 291, 1-32, 2002.

Ajayi, S. O., Odesanya, B. O., Avwioroko, A. O., Adebambo, G. S., and Okafor, B.: Effects of long term fertilizer use on trace metal levels of soils in a farm settlement, Journal of Agricultural Research and Development, 2, 044-051, 2012.

Alloway, B. J.: Heavy metals in soils, edited by: Alloway, B. J., Blackie, Glasgow and London, 1990.

Atafar, Z., Mesdaghinia, A., Nouri, J., Homaee, M., Yunesian, M., Ahmadimoghaddam, M., and Mahvi, A. H.: Effect of fertilizer application on soil heavy metal concentration, Environ. Monit. Assess., 160, 83-89, 2010.

Barak, P., Jobe, B. O., Krueger, A. R., Peterson, L. A., and Laird, D. A.: Effects of long-term soil acidification due to nitrogen fertilizer inputs in Wisconsin, Plant Soil, 197, 61-69, 1997.

Bationo, A., Kihara, J., Vanlauwe, B., Waswa, B., and Kimetu, J.: Soil organic carbon dynamics, functions and management in West African agro-ecosystems, Agr. Syst., 94, 13-25, 2007.

BBodSchV (Bundes- Bodenschutz- und Altlastenverordnung): Bundesgesetzblatt, Bundesanzeigerverlagsgesellschaft $\mathrm{mbH}$, Köln, Germany, 1999.

Bolan, N. S. and Hedley, M. J.: Role of Carbon, Nitrogen, and Sulfur Cycles in Soil Acidification, in: Handbook of soil acidity, edited by: Rengel, Z., Marcel Dekker, Inc., New York, 2003.

Brevik, E. C. and Sauer, T. J.: The past, present, and future of soils and human health studies, SOIL Discuss., 1, 51-80, doi:10.5194/soild-1-51-2014, 2014.

Cakmak, D., Saljnikov, E., Mrvic, V., Jakovljevic, M., Marjanovic, Z., Sikiric, B., and Maksimovic, S.: Soil properties and trace elements contents following 40 Years of phosphate fertilization. J. Environ. Qual., 39, 541-547, 2010.

Caravaca, F., Lax, A., and Albaladejo, J.: Organic matter, nutrient contents and cation exchange capacity in fine fractions from semiarid calcareous soils, Geoderma, 93, 161-196, 1999.

De Klein, C. A. M., Monaghan, R. M., and Sinclair, A. G.: Soil acidification: A provisional model for New Zealand pastoral systems, New Zeal. J. Agr. Res., 40, 541-557, 1997.

DIN ISO 10390: Soil quality - Determination of $\mathrm{pH}$, DIN Deutsches Institut für Normung e.V., Beuth, Berlin, Germany, 2005.

DIN ISO 10693 1997-05: Soil quality - Determination of carbonate content - Volumetric method, Deutsches Institut für Normung, Beuth Verlag GmbH, Berlin, 1997.

DIN ISO 11277: Soil quality - Determination of particle size distribution in mineral soil material - Method by sieving and sedimentation, DIN Deutsches Institut für Normung e.V., Beuth, Berlin, Germany, 2002.

DIN 19730 2009-07: Soil quality- Extraction of trace elements from soil using ammonium nitrate solution, Deutsches Institut für Normung, Beuth Verlag GmbH, Berlin, 2009.

Gong, W., Yan, X., Wang, J., Hu, T., and Gong, Y.: Long-term manure and fertilizer effects on soil organic matter fractions and microbes under a wheat-maize cropping system in northern China, Geoderma, 149, 318-324, 2009.
Grant, C. A.: Influence of phosphate fertilizer on cadmium in agricultural soils and crops, Pedologist, 143-155, 2011.

Gray, C. W., McLaren, R. G., Roberts, A. H. C., and Condron, L. M.: The effect of long-term phosphatic fertilizer applications on the amounts and forms of cadmium in soils under pasture in New Zealand, Nutr. Cycl. Agroecosys., 54, 267-277, 1999.

Hagen, B. and Howard, K.: The determination of boron, iron, magnesium and zinc in fertilizers using ICP-AES, Concordia College Journal of Analytical Chemistry, 2, 51-57, 2011.

Halvorson, A. D., Reule, C. A., and Follett, R. F.: Nitrogen Fertilization Effects on Soil Carbon and Nitrogen in a Dryland Cropping System, Soil Sci. Soc. Am. J., 63, 912-917, 1999.

Haynes, R. J. and Naidu, R.: Influence of lime, fertilizer and manure applications on soil organic matter content and soil physical conditions: a review, Nutr. Cycl. Agroecosys., 51, 123-137, 1998.

Hejcman, M. and Schnellberg, J.: Fertilizer application on grassland - history, effects and scientific value of long-term experimentation, in: Fertilizers: properties, applications and effects, Nova Science Publishers, Inc., New York, 83-106, 2009.

Huang, B., Kuo, S., and Bembenek, R.: Availability of cadmium in some phosphorous fertilizers to field-grown lettuce, Water Air Soil Poll., 158, 37-51, 2004.

IUSS Working Group WRB: World Reference Base for Soil Resources 2014. International soil classification system for naming soils and creating legends for soil maps, World Soil Resources Reports No. 106, FAO, Rome, 2014.

Kabata-Pendias, A.: Trace elements in soils and plants, 4th Edn., CRC Press LLC, Boca Raton, 2011.

Kabata-Pendias, A. and Mukherjee, A. B.: Trace elements from soil to human, Springer-Verlag Berlin Heidelberg, 2007.

Liang, Q., Chen, H., Gong, Y., Fan, M., Yang, H., Lal, R., and Kuzyakov, Y.: Effects of 15 years of manure and inorganic fertilizers on soil organic carbon fractions in a wheat-maize system in the North China Plain, Nutr. Cycl. Agroecosyst., 92, 21-33, 2012.

Liu, J., Duan, C.-Q., Zhu, Y.-N., Zhang, X.-H., and Wang, C.-X.: Effect of chemical fertilizers on the fractionation of $\mathrm{Cu}, \mathrm{Cr}$ and Ni in contaminated soil, Environ. Geol., 52, 1601-1606, 2007.

Liu, X., Liu, J., Xing, B., Herbert, S. J., Meng, K., Han, X., and Zhang, X.: Effects of long-term continuous cropping, tillage, and fertilization on soil organic carbon and nitrogen of Black Soils in China, Commun. Soil Sci. Plan., 36, 1229-1239, 2005.

Loganathan, P., Hedley, M. J., Gregg, P. E. H., and Currie, L. D.: Effect of phosphate fertilizer type on the accumulation and plant availability of cadmium in grassland soils, Nutr. Cycl. Agroecosys., 47, 169-178, 1997.

Mazzoncini, M., Sapkota, T. B., Barberi, P., Antichi, D., and Risaliti, R.: Long-term effect of tillage, nitrogen fertilization and cover crops on soil organic carbon and total nitrogen content, Soil Till. Res., 114, 165-174, 2011.

McLaughlin, M. J., Parker, D. R., and Clarke, J. M.: Metals and micronutrients - food safety issues, Field Crop Res., 60, 143163, 1999.

Messiga, A. J., Ziadi, N., Belanger, G., and Morel, C.: Soil nutrients and other major properties in grassland fertilizes with nitrogen and phosphorus, Soil Sci. Soc. Am. J., 77, 643-652, 2013.

Nicholson, F. A., Smith, S. R., Alloway, B. J., Carlton-Smith, C., and Chambers, B. J.: An inventory of heavy metals inputs to 
agricultural soils in England and Wales, Sci. Total Environ., 311, 205-219, 2003.

Öztan, S. and Düring, R.-A.: Microwave assisted EDTA extractiondetermination of pseudo total contents of distinct trace elements in solid environmental matrices, Talanta, 99, 594-602, 2012.

Papafilippaki, A., Gaparato, D., Haidouti, S., and Stavroulakis, G.: Total and Bioavailable forms of $\mathrm{Cu}, \mathrm{Zn}, \mathrm{Pb}$ and $\mathrm{Cr}$ in Agricultural soils: A Study from the Hydrological Basin of Keritis, Chania, Greece, Global NEST Journal, 9, 201-206, 2007.

Puschenreiter, M. and Horak, O.: Influence of different soil parameters on the transfer factor soil to plant of $\mathrm{Cd}, \mathrm{Cu}$ and $\mathrm{Zn}$ for wheat and rye, Die Bodenkultur, 51, 3-10, 2000.

Radulov, I., Berbecea, A., Sala, F., Crista, F., and Lato, A.: Mineral fertilization influence on soil $\mathrm{pH}$, cationic exchange capacity and nutrient content, Res. J. Agric. Sci., 43, 160-165, 2011.

Rashidi, M. and Seilsepour, M.: Modelling of soil cation exchange capacity based on soil organic carbon, ARPN J. Agr. Bio. Sci., 3, 41-45, 2008.

Raskin, I., Kumar, P. B. A. N., Dushenkov, S., and Salt, D. E.: Bioconcentration of heavy metals by plants, Curr. Opin. Biotech., 5, 285-290, 1994

Rasool, R. Kukal, S. S., and Hira, G. S.: Soil organic carbon and physical properties as affected by long-term application of FYM and inorganic fertilizers in maize-wheat system, Soil Till. Res., 101, 31-36, 2008.

Raun, W. R., Johnson, G. V., Phillips, S. B., and Westerman, R. L.: Effect of long-term $\mathrm{N}$ fertilization on soil organic $\mathrm{C}$ and total $\mathrm{N}$ in continuous wheat under conventional tillage in Oklahoma, Soil Till. Res., 47, 323-330, 1998.

Raven, K. P., Reynolds, J. W., and Loeppert, R. H.: Trace Element Analyses of Fertilizers and Soil Amendments by Axial-View Inductively-Coupled Plasma Atomic Emission Spectrophotometry, Commun. Soil Sci. Plan., 28, 237-257, 1997.
Ritchie, G. S. P. and Dolling, P. J.: The role of organic matter in soil acidification, Aust. J. Soil Res., 23, 569-576, 1985.

Schjonning, P., Christensen, B. T., and Carstensen, B.: Physical and chemical properties of a sandy loam receiving animal manure, mineral fertilizer or no fertilizer for 90 years, Eur. J. Soil Sci., 45, 257-268, 1994.

Schwab, A. P., Owensby, C. E., and Kulyingyong, S.: Changes in soil chemical properties due to 40 years of fertilization, Soil Sci., 149, 35-43, 1990.

Thomas, E. Y., Omueti, J. A. I., and Ogundayomi, O.: The Effect of Phosphate Fertilizer on Heavy Metal in Soils and Amaranthus Caudatus, Agr. Biol. J. N. Am., 3, 145-149, 2012.

Trüby, P. and Aldinger, E.: Eine Methode zur Bestimmung austauschbarer Kationen in Waldböden, Z. Pflanz. Bodenkunde, 152, 301-306, 1989.

Tsadilas, C. D., Karaivazoglou, N. A., Tsotsolis, N. C., Stamatiadis, S., and Samaras, V.: Cadmium uptake by tobacco as affected by liming, $\mathrm{N}$ form, and year of cultivation, Environ. Pollut., 134, 239-246, 2005.

Ure, A. M.: Trace elements in soil: Their determination and speciation Fresenius, J. Anal. Chem., 337, 577-581, 1990.

USEPA (US Environmental Protection Agency): Microwave assisted acid digestion of sediments, sludges, soils, and oils, Method 3051a, Office of Solid Waste and Emergency Response, US Government Printing Office, Washington, DC, 1998.

Xie, W. J., Wang, H. Y., Xia, J. B., and Yao, Z. G.: Influence of $\mathrm{N}, \mathrm{P}$, and $\mathrm{K}$ application on Zea mays $\mathrm{L}$. growth and $\mathrm{Cu}$ and $\mathrm{Pb}$ accumulation, Plant Soil Environ., 57, 128-134, 2011.

Zhou, Q.: Interaction between Heavy Metals and Nitrogen Fertilizers Applied to Soil-Vegetable Systems, Bull. Environ. Contam. Tox., 71, 338-344, 2003. 